
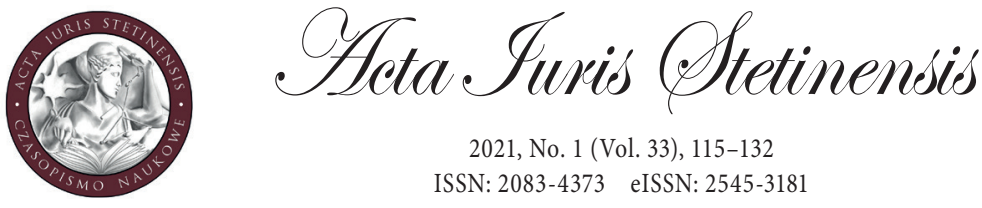

2021, No. 1 (Vol. 33), 115-132

ISSN: 2083-4373 eISSN: 2545-3181

DOI: $10.18276 /$ ais.2021.33-07

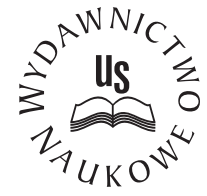

Łukasz Mroczyński-Szmaj

MA

University of Rzeszów, Poland

College of Social Sciences

open access

Institute of Legal Studies

Department of Civil and Commercial Law

e-mail:lmroczynski@ur.edu.pl

ORCID ID: 0000-0002-4256-5136

\title{
Digitalisation of ADR proceedings in consumer cases, with particular emphasis on the institutions of the Financial Ombudsman and Coordinator for Negotiations
}

\begin{abstract}
The purpose of this paper is to present changes in legislation during 2013-2017 in the area of consensual dispute resolution with the participation of consumers-in particular with regard to the emergence of electronic procedures. Various features of the analysis of law in force as well as the analysis of law as has it evolved in history are used in the implementation of this objective. The author addresses model European solutions provided under Regulation (EU) No 524/2013 of the European Parliament and of the Council of 21 May 2013 on online dispute resolution for consumer disputes and amending Regulation (EC) No 2006/2004 and Directive 2009/22/EC (Regulation on consumer ODR) and presents two important institutions of consensual dispute resolution with the participation of consumers within the framework of the European ODR platform. The author concludes that the introduction of digital procedures cuts down expenses, the duration of disputes and provides a realistic option of achieving its final result; it is also stressed that this is of particular significance in the resolution of cross-border disputes within 90 days - where we encounter obstacles in
\end{abstract}


the form of different national legal orders or language barriers. The author furthermore indicates that an important advantage of the ODR platform consists in the possibility of going through intuitive steps with the assistance of complaint creators, recording drafts, and checking consumer rights, which is very convenient for consumers, who are not particularly proficient in the operation of mobile devices. However, the author also notes that the various institutions involved in the out-of-court dispute resolution may differ in their legal status or possibilities of resolving a particular dispute (for example, the Financial Ombudsman and the Coordinator for negotiations cannot deliver binding arbitration decisions). By the same token, in selecting an ODR entity, it must be borne in mind that not all of them can resolve a dispute between parties in a binding manner.

Keywords: digitalization, consumer, Financial Ombudsman, Coordinator for negotiations, online dispute resolution (ODR)

\section{Introduction}

One of the fundamental phenomena in today's global economy is general digitalization. This will primarily involve the transformation from traditional, real forms of executing certain transactions into forms of transactions executed with the assistance of a mobile device with internet access (in particular, smartphone, tablet or computer), the result of which will be reflected in the real world. The new market - with even more intense global sales of goods and services via the internet, also prompts keeping pace with them by legislative systems through the provision of an appropriate legal framework with a view to protecting the parties to contracts concluded in the virtual world, as well at the time of emergence of disputes regarding particular transactions, which allows expedient, low-cost and online dispute resolution. EU legislation primarily aims at meeting this task, and consequently the national legislation of Member States follows suit. Such tendencies are expressed by Regulation (EU) No 524/2013 of the European Parliament and of the Council of 21 May 2013 on online dispute resolution for consumer disputes and amending Regulation (EC) No 2006/2004 and Directive 2009/22/EC (Regulation on consumer ODR $)^{1}$ and Directive 2013/11/EU of the European Parliament and of the Council of 21 May 2013 on alternative dispute resolution for consumer disputes and amending Regulation (EC) No 2006/2004 and Directive 2009/22/EC (the ADR Directive $)^{2}$, transposed into the Polish legal order by the Out-of-court Consumer

\footnotetext{
1 OJ L 165, 18.6.2013, p. 1.

2 OJ L 165, 18.6.2013, p. 63.
} 
Dispute Resolution Act of 23 September 2016. ${ }^{3}$ Thanks to this new legislation, a real effort has been taken with a view to providing a system of dispute resolution with the participation of weaker market participants, that is consumers. In this regard, the author of this paper will be primarily focusing on two institutions operating in the area of consensual dispute resolution: the Financial Ombudsman ${ }^{4}$ and the Coordinator for negotiations. The choice of these entities entitled to conduct ADR proceedings is not accidental, as legal relationships of consumers in the financial sector and the power sector are (or may be) highly vulnerable to the use of contractual advantage by the entrepreneur which is a party of such a relationship (for example, credits in Swiss Francs or electricity price hikes). Bearing the above in mind, the paper demonstrates the mechanisms of the operation of both entities, taking into account the digitalization of ADR proceedings (i.e. transformation into Online Dispute Resolution-ODR), which is a novelty in light of the presented ADRkonsU).

\section{The ODR phenomenon. Existence and forms}

The relevant literature indicates that the phenomenon of online dispute resolution had preceded EU solutions adopted in 2013. ${ }^{5}$ Although international and national legislation does not provide a normative definition of the concept of Online Dispute Resolution, the literature provides that it is to be understood as forms of online dispute resolution with the use of Alternative Dispute Resolution mechanisms (ADR). ${ }^{6}$ The scope of this concept shall include disputes resolved in a partial or

3 Dz.U. (Journal of Laws) 2016, item 1823; hereinafter: ADRkonsU.

4 J. Kalak, Pozasądowe postępowanie w sprawie rozwiązywania sporów między klientem a podmiotem rynku finansowego, "Kwartalnik ADR" 2016, No. 2, pp. 17ff.

5 The Online Ombuds Office was established in 1996 in the United States, at the Center for Information Technology and Dispute Resolution at the University of Massachusetts, subsequently transformed into SquareTrade which operates eBay or-since 1998-CyberSettle, which offers, as one of first such portals, automated electronic mediation. Source: K. Mania, Online Dispute Resolution, in: J. Czapska et al. (eds.), Mediacja. Teoria, normy, praktyka, Warszawa 2017, pp. 361-362.

6 K. Mania, Online..., op. cit., pp. 363ff. Other terms include: Eletronic ADR (eADR), Online ADR (oADR), or Internet Dispute Resolution (iADR). See also: K. Mania, ODR (Online Dispute Resolution) - podstawowe zagadnienia, "Arbitraż i Mediacja" 2010, No. 2, p. 74 and A. Bieliński, Uwagi wstępne na temat mediacji, in: J. Olszewski (ed.), Sądy polubowne i mediacja, Warszawa 2008, pp. 37-47. 
complete manner on the internet, which have arose both in the virtual world, as well as outside it. ${ }^{7}$

Europe provides examples of entities which offer out-of-court dispute resolution $^{8}$, inter alia, ProMediate online mediation ${ }^{9}$ in the UK, the RisolviOnline ${ }^{10}$ of the Milan Chamber of Arbitration in Italy or digital arbitration in Spain, represented by ConfianzaOnline. ${ }^{11} \mathrm{~S}$. Pieckowski notes that the ODR method has already been applied in Poland by the arbitration court ${ }^{12}$ of the Polish IT Chamber ${ }^{13}$, created by NASK-Scientific and Academic Computer Network. ${ }^{14}$ As noted by Pieckowski, such ODR arbitration proceedings last 30 days on average and are much more low$\operatorname{cost}^{15}$. S. Pieckowski also cites the example of another ODR entity indicating that as regards disputes concerning the European domain: "eu", the Czech Arbitration Court in Prague ${ }^{16}$ has jurisdiction: "(...) online arbitration proceedings are held [before this court], in principle exclusively by means of electronic communication; the arbitration court, usually consisting of one arbitrator, does not contact the parties, it reviews procedural documents along with annexed evidence, which it receives from the court's registry, and provides rulings. It must be stressed that in major matters difficult in terms of evidence, the court's rules and regulations allow for a hearing with the participation of the parties and witnesses". ${ }^{17}$

In classifying the various ODR types, K. Mania notes that each form may have a differently shaped course of the process, and highlights, in particular, that already online mediation may take different forms: for example, a fully automated internet

7 M.S. Abdel Wahab, E. Katsch and D. Rainey, Online Dispute Resolution: Theory and Practice: A Treatise on Technology and Dispute Resolution, The Hague 2012.

8 Source: K. Mania, Online..., op. cit., p. 365.

9 ProMediate Mediation Services - What we do, ProMediate Mediation Services, https://www.promediate.co.uk/ (accessed 31.07.2020).

10 Online Dispute Resolution Service - Milan Chamber of Arbitration, https://www.risolvionline. com/index.php, (accessed 31.07.2020).

11 Online Dispute Resolution Service, https://www.confianzaonline.es/en/ (accessed 31.07.2020).

12 See T. Faliszek, ODR. Rozpatrywanie sporów z zakresu sporów domenowych, in: B. Fuchs and J. Olszewski (eds.), Arbitraż. Między teorią a praktyką, Rzeszów 2014, pp. 174-186.

13 At the present: Court of Arbitration for Internet Domains, Polish IT Chamber, https://www.piit. org.pl/sad-polubowny (accessed 31.07.2020).

14 S. Pieckowski, in: A. Szumański (ed.), Arbitraż Handlowy. System Prawa Handlowego, Vol. 8, Warszawa 2015, p. 1138.

15 Ibidem, p. 1138.

16 Arbitration Court to the Chamber of Commerce of the Czech Republic and the Agricultural Chamber of the Czech Republic, Online Service, https://en.soud.cz (accessed 31.07.2020).

17 S. Pieckowski, op. cit. p. 1138. 
platform, as well as networks which employ tools such as chats or videoconferences, and finally, so-called asynchronous forms of communication, such as e-mail. ${ }^{18} \mathrm{On}$ the one hand, this shows that ODR comes in many forms, on the other, this means that users of such tools must take their decisions most carefully, if only by reason of the consequences of not addressing a procedural matter in the ODR proceduree-arbitration within the prescribed deadline-due to failure to read an e-mail, as regards asynchronous forms).

\section{The digital market as part of the EU internal market. European ODR Platform}

The EU is still searching for new areas of regulation, in which it may appear in terms of technology and legislation. For this very reason, the following report concerning the level of ADR application, has, inter alia, been prepared: Cross-Border Alternative Dispute Resolution in the European Union ${ }^{19}$. Undoubtedly, based on this very document, a comprehensive ADR legislative package for the EU has been prepared-that is, the cited Regulation on consumer ODR and the ADR Directive, both concerning consumer disputes.

The Regulation on consumer ODR warrants particular attention. Its Recital 6 states that "(...) The digital dimension of the internal market is becoming vital for both consumers and traders. Consumers increasingly make purchases online and an increasing number of traders sell online. Consumers and traders should feel confident in carrying out transactions online so it is essential to dismantle existing barriers and to boost consumer confidence. The availability of reliable and efficient online dispute resolution (ODR) could greatly help achieve this goal". In this regard, it follows from Recital 8 of this Regulation that ODR offers a simple, efficient, fast and low-cost out-of-court solution to disputes arising from online transactions. However, it also stresses that prior to the entry into force of the Regulation, there had been a lack of mechanisms which allow consumers and traders to resolve such disputes through electronic means; this leads to consumer detriment, acts as a barrier, in particular, to cross-border online transactions, and creates an uneven playing field for traders, and thus hampers the overall development of online commerce.

18 K. Mania, Online..., op. cit., p. 366.

19 Directorate General For Internal Policies Policy Department A: Economic And Scientific Policy Internal Market And Consumer Protection, Cross-Border Alternative Dispute Resolution in the European Union, June 2011, http://www.europarl.europa.eu/meetdocs/2009_2014/documents/ imco/dv/adr_study_/adr_study_en.pdf as at 31.07.2020. 
With a view to countering such a state of affairs, the EU legislature prepared a solution binding on EU Member States, i.e. the so-called ODR Platform. When it launched on 15 February 2016, there had been little consumer knowledge on out-of-court online dispute resolution ${ }^{20}$. Under Article 5(1) of the Regulation, the European Commission was charged with the task of preparing the ODR Platform and was "(...) responsible for its operation, including all the translation functions necessary for the purpose of this Regulation, its maintenance, funding and data security (...)". What is more important, it had already been stated at this stage that the ODR platform shall be user-friendly. The development, operation and maintenance of the ODR platform shall ensure that the privacy of its users is respected from the design stage. The Regulation on consumer ODR charged Member States with the task to ensure that the ODR platform is accessible and usable by all, including vulnerable users, as far as possible.

Under Article 5(2) of the Regulation on consumer ODR, the ODR platform is a single point of entry for consumers and traders seeking the out-of-court resolution of disputes; it shall be an interactive website which can be accessed electronically and free of charge in all the official languages of the institutions of the EU.

The detailed scope of functions has also been set out in the regulation in question, and accordingly, under Article 5(4), the ODR platform has the following functions:

- to provide an electronic complaint form which can be filled in by the complainant party in accordance with Article 8;

- to inform the respondent party about the complaint;

- to identify the competent ADR entity or entities and transmit the complaint to the ADR entity, which the parties have agreed to use, in accordance with Article 9;

- to offer an electronic case management tool free of charge, which enables the parties and the ADR entity to conduct the dispute resolution procedure online through the ODR platform;

- to provide the parties and ADR entity with the translation of information which is necessary for the resolution of the dispute and is exchanged through the ODR platform;

- to provide an electronic form by means of which ADR entities shall transmit the information referred to in point (c) of Article 10;

- to provide a feedback system which allows the parties to express their views on the functioning of the ODR platform and on the ADR entity which has handled their dispute;

20 K. Mania, Online..., op. cit., p. 365. 
- to make publicly available the general information on ADR and statistical data. Under Article 7 of the Regulation, each Member State shall designate one ODR contact point and communicate its name and contact details to the Commission. The Member States may confer responsibility for the ODR contact points on their centres of the European Consumer Centres Network, on consumer associations or on any other body. The Polish contact point operates under the President of the Office of Competition and Consumer Protection ${ }^{21}$. Each ODR contact point shall host at least two ODR advisors. ODR contact points together form the Network of ODR contact points.

\section{Polish ODR bodies}

The catalogue of active Polish ODR bodies ${ }^{22}$ can be found on the ODR platform website, and its detailed list as at 31 July 2020 is also in the footnote. ${ }^{23}$ Of course,

21 Polubowne rozwiązywanie sporów konsumenckich, UOKiK, https://www.uokik.gov.pl/pozasadowe_ rozwiazywanie_sporow_konsumenckich.php (accessed 31.07.2020).

22 Dispute resolution bodies, European Commission, https://ec.europa.eu/consumers/odr/main /? event=main.adr.show2 (accessed 31.07.2020).

23 ULTIMA RATIO Pierwszy Elektroniczny Sąd Polubowny przy Stowarzyszeniu Notariuszy Rzeczypospolitej Polskiej w Warszawie (ULTIMA RATIO, First Electronic Court of Arbitration, Association of Notaries of the Republic of Poland, Warsaw, Centrum Polubownego Rozwiązywania Sporów dot. Żywności (Centre for Amicable Settlement of Food Disputes), Dolnośląski Wojewódzki Inspektor Inspekcji Handlowej we Wrocławiu (Dolnośląskie Provincial Inspector of the Trade Inspection Authority in Wrocław), Izba Gospodarki Elektronicznej (Chamber of Electronic Economy), Koordynator do spraw negocjacji przy Prezesie Urzędu Regulacji Energetyki (Coordinator for negotiations to the President of the Energy Regulatory Office), Kujawsko-Pomorski Wojewódzki Inspektor Inspekcji Handlowej w Bydgoszczy (Kujawsko-Pomorskie Provincial Inspector of the Trade Inspection Authority in Bydgoszcz), Łódzki Wojewódzki Inspektor Inspekcji Handlowej w Łodzi (Łódzkie Provincial Inspector of the Trade Inspection Authority in Łódź), Lubelski Wojewódzki Inspektor Inspekcji Handlowej w Lublinie (Lubelskie Provincial Inspector of the Trade Inspection Authority in Lublin), Lubuski Wojewódzki Inspektor Inspekcji Handlowej w Gorzowie Wielkopolskim (Lubuskie Provincial Inspector of the Trade Inspection Authority in Gorzów Wielkopolski), Małopolski Wojewódzki Inspektor Inspekcji Handlowej w Krakowie (Małopolskie Provincial Inspector of the Trade Inspection Authority in Kraków), Mazowiecki Wojewódzki Inspektor Inspekcji Handlowej w Warszawie (Mazowieckie Provincial Inspector of the Trade Inspection Authority in Warsaw), Opolski Wojewódzki Inspektor Inspekcji Handlowej w Opolu (Opolskie Provincial Inspector of the Trade Inspection Authority in Opole), Podkarpacki Wojewódzki Inspektor Inspekcji Handlowej w Rzeszowie (Podkarpackie Provincial Inspector of the Trade Inspection Authority in Rzeszów), Podlaski Wojewódzki Inspektor Inspekcji Handlowej w Białymstoku (Podlaskie Provincial Inspector of the Trade Inspection Authority in Białystok), Pomorski Wojewódzki Inspektor Inspekcji Handlowej w Gdańsku (Pomorskie Provincial Inspector of the Trade Inspection Authority in Gdańsk), Prezes Urzędu Komunikacji Elektronicznej (President of the Office of Electronic Communications), Rzecznik Finansowy (Financial 
a presentation of all of these institutions merits a separate paper. Just the same, due to the particular detrimental effects for the consumer of financial services (indebtedness, bankruptcy) and energy (getting cut-off from electrical power, gas, heating), this presentation is limited to two representative institutions. Due to the applied model solutions both institutions are presented in a descriptive manner, and subsequently, with the assistance of a table synthesis, the adequate conclusions have been inferred.

\section{The Financial Ombudsman}

One of the two selected institutions for detailed discussion in this paper is the Financial Ombudsman, which has effectively evolved through the transformation of the Insurance Ombudsman, ${ }^{24}$ already operating since 1995. Like its institutional predecessor, the Financial Ombudsman was originally the legislature's response to the current problems of the financial market. ${ }^{25}$ The institution in question was established by the Act of 5 August 2015 on the review of complaints by entities of the

Ombudsman), Rzecznik Praw Pasażera Kolei przy Prezesie Urzędu Transportu Kolejowego (Rail Passenger Rights Ombudsman to the President of the Office of Rail Transport), Rzecznik Praw Pasażerów przy Prezesie Urzędu Lotnictwa Cywilnego (The Passengers Rights Ombudsman at the office of the President of the Civil Aviation Authority; air transport disputes arising from Regulations: (EC) No 261/2004 and (EC) No 2111/2005); Sąd Polubowny przy Komisji Nadzoru Finansowego (Arbitration Court at the Polish Financial Supervision Authority), Śląski Wojewódzki Inspektor Inspekcji Handlowej w Katowicach (Śląskie Provincial Inspector of the Trade Inspection Authority in Katowice), Świętokrzyski Wojewódzki Inspektor Inspekcji Handlowej w Kielcach (Świętokrzyskie Provincial Inspector of the Trade Inspection Authority in Kielce), Warmińsko-Mazurski Wojewódzki Inspektor Inspekcji Handlowej w Olsztynie (Warmińsko-Mazurskie Provincial Inspector of the Trade Inspection Authority in Olsztyn), Wielkopolski Wojewódzki Inspektor Inspekcji Handlowej w Poznaniu (Wielkopolskie Provincial Inspector of the Trade Inspection Authority in Poznań), Zachodniopomorski Wojewódzki Inspektor Inspekcji Handlowej w Szczecinie (Zachodniopomorskie Provincial Inspector of the Trade Inspection Authority in Szczecin), Związek Banków Polskich Bankowy Arbitraż Konsumencki (Polish Bank Association-Banking Consumer Arbitration).

24 Under the defunct law of 8 June 1995 amending the Law on insurance activity amending the Regulation of the President of the Republic of Poland - the Commercial Code and amending the Corporate Income Tax Act, Dz.U. (Journal of Laws) of 1995, No. 96, item 478, as amended. Further reading on this institution: K. Koc, K., Rzecznik Ubezpieczonych, in: A. Gronkiewicz (ed.), Instytucje ombudsmańskie w Polsce (wybrane zagadnienia), Częstochowa 2013.

25 The establishment of the Insurance Ombudsman in 1995 was a direct response to the failures of a number of insurance companies, whereas the background of the establishment of the Financial Ombudsman in 2015 was the so-called AmberGold Affair and borrowers' problems with loans denominated in Swiss Francs. 
financial market and on the Financial Ombudsman ${ }^{26}$ (hereinafter the "ReklamU"), and ADRkonsU modified it in the aspect of its operation as an ADR body. However, it must be stressed in this regard that the Financial Ombudsman ${ }^{27}$ is not a body which is only entitled to conduct proceedings dealing with out-of-court dispute resolution, but its powers also include, inter alia ${ }^{28}$ :

- provision of opinions on legislation concerning the organization and operation of financial market players,

- submission of requests with the competent authorities for initiating legislation or for the adoption or modification of other legislation concerning the organization and operation of financial market players should the need arise,

- informing the competent regulatory and inspection authorities on observed irregularities in the operation of financial market players,

- initiation and organization of educational and information activities in the area of protecting the interests of consumers of financial market players.

It must also be highlighted that the Financial Ombudsman is also competent to bring legal action on behalf of customers in matters concerning unfair market practices as regards the operation of financial market players, as well as - with the consent of the applicant - to participate in already pending court proceedings. ${ }^{29}$ However, the institution has not been the subject of any detailed analyses in this regard.

The Financial Ombudsman is a body entitled to conduct out-of-court dispute resolution proceedings and reviews both national and cross-border disputes, including consumer ODR. The provisions of Chapter 4 ReklamU provide details of its operation, i.e. Articles $35-43$ and, adopted pursuant to these provisions, the Regulation of the Minister of Development of 15 February 2017 concerning outof-court proceedings before the Financial Ombudsman ${ }^{30}$ (hereinafter the Financial Ombudsman ADR Regulation). Under Article 35b(1) ReklamU, ADR proceedings are conducted by a person authorized by the Ombudsman; such authorization is granted for a specific period of time ${ }^{31}$. Such authorization should be granted to, in

26 Consolidated text, Dz.U. (Journal of Laws) 2019, item 2279.

27 See also: J. Klak, op. cit., pp. 17ff.

28 Quoted from: Explanatory memorandum of draft law - Sejm Paper no. 3430, Deputies' draft law concerning the review of complaints by financial market players, http://www.sejm.gov.pl/Sejm7. nsf/druk.xsp?nr=3430 (accessed 31.07.2020).

29 Ibidem.

30 Dz.U. (Journal of Laws) 2017, item 313.

31 The Financial Ombudsman grants authorization for conducting proceedings for a specified period of time, no less than 6 months and no more than 3 years. 
particular, a person who is outstanding in knowledge of the operation of financial markets and of the legal regulations governing its environment, and who has at least 5 years of working experience, including at least 3 years of working experience in this area (Article 35b(2) ReklamU).

Further to the adopted regulations, the proceedings are instituted following an application made by the customer of the financial market entity (Article 36 Rekl$\mathrm{amU}$ ). The application for instituting proceedings shall, as a minimum, contain the elements specified in Article 33(2) ADRkonsU, that is, the indication of the parties, precise specification of request, indication of the type of proceedings in accordance with the applicant's choice, and his/her signature; however, the applicant may, within the framework of proceedings, request:

- that the approximation of the parties' positions be enabled with a view to resolving the dispute by the parties thereto, or

- that a proposal for resolving the dispute to the parties thereto be presented.

Under Article 36(3) ReklamU, the following shall be annexed to the application: a description of the circumstances of the case, information as to the current course of the dispute and copies of documents in the applicant's possession which substantiate the information contained in the application.

As clarified under Article 4(1) of the Financial Ombudsman ADR Regulation, the proceedings or parts thereof shall be performed in writing or by means of electronic communication. Correspondence shall be incorporated into the case file, and the file itself may be kept in electronic form. Also, the Financial Ombudsman informs the parties about its actions in writing and where possible and supported by the facts of the case - by means of electronic communication.

The application submitted by the customer of the financial market entity which initiates the proceedings may be sent by post to the address of the Office of the Financial Ombudsman, or by means of electronic communication, in a form and to the address indicated at the Financial Ombudsman's website.

What is more important, the professional entity is obliged to accede to such proceedings. ${ }^{32}$ The question whether consensual proceedings are mandatory arises at this point. As a rule, however, it must be noted that mandatory $\mathrm{ADR}^{33}$ exists in the legal orders of European countries, and their legality is not challenged. ${ }^{34}$

32 Łatwiej o polubowne rozwiazanie sporu, Financial Ombudsman, https://rf.gov.pl/sprawy-biezace/ Latwiej_o_polubowne_rozwiazanie_sporu_22501 (accessed 31.07.2020).

33 See: K. Gajda-Roszczynialska, Mediacja obligatoryjna, "Polski Proces Cywilny" 2012, No. 13, pp. 437ff.

34 J. Klak, op. cit., pp. 25ff.; A. Okońska, Mediacja - Austria, Niemcy, Szwajcaria, in: A. Torbus (ed.), Mediacja w sprawach gospodarczych. Praktyka - teoria - perspektywy, Warszawa 2015, pp. 59ff. 
The application form provided on the Financial Ombudsman's website contains the elements set out in Article 6(1) of the Financial Ombudsman ADR Regulation, that is:

- indication of the customer of the financial market player, hereinafter the "customer", including his/her first name and surname, address of residence and address for correspondence, where it differs from the residence address, as well as the phone number and e-mail address, if the customer has one;

- indication of the financial market player, including its name and address of its seat;

- precise specification of the customer's request, including the value of the monetary claim or desired conduct;

- indication of the expectation as to how the dispute must close;

- description of the facts of the case;

- indication of the type of proceedings referred to in Article 36(2) of the Act, by indicating that the applicant requests the approximation of the parties' position with a view to resolving the dispute by the parties thereto or a presentation of a proposal for resolving the dispute;

- signature of the customer or his/her attorney-in-fact.

It is worth noting that the accuracy of data and description of the presented case bears a significant impact on the timeframe of the proceedings. Deficiencies in this regard at times cause a significant extension of the initial stage of the proceedings, and unfortunately may constitute an element of a negative "procedural game for delaying proceedings" on the part of the consumer or his/her attorney-in-fact.

The following shall be attached to such an application (Article 6(2)):

- documents held by the applicant in support of the described facts of the case or information that such documents are lacking;

- a document confirming the completion of complaint proceedings or indication of circumstances preventing the attachment thereof;

- proof of payment of the fee or a request for an exemption from payment thereof;

- power-of-attorney, where the application is lodged by an attorney;

- information whether the Ombudsman is taking or has taken any action under Article 17(1)(1) and (2) of the Act with regard to the protection of customers of financial market players, by representing the customer's interests, as well as information whether a case concerning the very same claim between the same parties is pending or has already been reviewed by the Ombudsman under relevant proceedings, by a court of arbitration, or a separate competent body or court (Article 6(3)).

A supplemented application must be signed by the party by hand. If the party sends the application via e-mail, they must attach a scan of the signed application. 
Where a scan of the application has been sent via e-mail, it is no longer necessary to send the original application by traditional post.

Where the application does not meet the above specified requirements, the Financial Ombudsman shall invite the applicant, under pain of not having the application reviewed, to have it supplemented within 14 days following the service of notice to this effect.

The Ombudsman shall inform the parties about the instituting of proceedings within 7 days (Article 10(1)). The outcome of the proceedings in the form of a protocol provided under Article 41(1) ReklamU shall be presented by the Ombudsman to the parties within 90 days from the date of receipt of an application which satisfies the aforementioned formal requirements. Where there is an extension of this period in the event of particularly complicated disputes, the Financial Ombudsman shall inform the parties to the proceedings of it and indicate the date of completion.

Finally, the Financial Ombudsman presents the parties with a proposal of resolving the dispute within the scope of request specified in the application, where the facts of the case allow formulation of such a proposal. The Ombudsman shall prescribe a deadline of no less than 7 days for the parties to approve of the presented proposal for resolving the dispute.

As a rule, the proceedings are performed without the personal appearance of the parties, although under Article 13(1) of the Financial Ombudsman ADR Regulation, should the need arise, when the nature of the dispute suggests so, the Ombudsman may schedule a sitting to which a party or parties shall be summoned. The sitting shall be scheduled for a date which allows a party or parties and their attorneys, if appointed, to appear.

The above is a brief presentation of the rules of procedure before the Financial Ombudsman, which demonstrates that we are dealing with a modern and efficient institution, adapted to the present challenges-even the Covid-19 pandemic, and that it is an authorized body in a situation where we must act remotely. There can therefore be no doubt that the information appearing in the media as regards the possibility of combining the institution in question with the President of the Office of Competition and Consumer protection, would not, from a general standpoint, be beneficial for consumer protection in the financial market - and accordingly, would decrease the level of consumer protection in this sector.

\section{Coordinator for negotiations}

The second institution discussed is the Coordinator for negotiations to the President of the Energy Regulatory Office. In terms of purpose, the Ombudsman of Fuel 
and Energy Recipients can be considered as its institutional predecessor ${ }^{35}$. The basis of its operation is laid down in the provisions of ADRkonU, which entered into force on 10 January 2017 and amended the Energy Law of 10 April $1997^{36}$ (also referred to as: PrEnerg), by adding Chapter IVa, and accordingly, Articles $31 \mathrm{a}-31 \mathrm{f}$, which regulate the legal status of the new institution. In contrast to the Financial Ombudsman, this is an institution which only conducts out-of-court dispute resolution proceedings. Due to the specific nature of this sector, proceedings before the Coordinator for negotiations (under Article 31a of the Energy Law) concern disputes between the recipients of gaseous fuel, electricity or heating for the household and power companies, and between prosumers who are consumers and power companies, arising under the following types of contracts:

- contracts for the connection to power grids, gas or heating networks, including connection of micro-installations;

- contracts for electrical power or natural gas transmission or distribution services;

- contracts for heat transmission and distribution services;

- sales contracts;

- comprehensive contracts.

On the other hand, just like the Financial Ombudsman, the Coordinator for negotiations, when conducting out-of-court dispute resolution proceedings:

- enables the approximation of the parties' positions with a view to resolving the dispute by the parties thereto, or

- presents a proposal for resolving the dispute to the parties thereto.

However, the context of the operation of both bodies differs, as the Financial Ombudsman, when acting outside the sphere of out-of-court dispute resolution, also has certain decision-making powers with regard to professional financial market players, which the Coordinator for negotiations simply does not have lacks with regard to professional energy market players, and is limited only to ADR proceedings. Moreover, when it comes to the power sector, a professional entity is not legally obliged to participate in ADR proceedings.

A precondition of lodging an application for conducting proceedings by the entitled body, that is, the Coordinator for negotiations involves the obligation of

35 See: J. Bełkowski, O zadaniach Rzecznika Odbiorców Paliw i Energii, "Biuletyn URE” 2002 No. 5, pp. 29-30; Ł. Mroczyński-Szmaj, Rola oraz ewolucja prawna instytucji Rzecznika Odbiorców Paliw i Energii w zakresie ochrony konsumenta, in: M. Czarnecka (ed.), Konsument na rynku energii elektrycznej, Warszawa 2013, pp. 159-182. Contrary to the above: I. Figaszewska, Zadania Rzecznika Odbiorców Paliw i Energii w Urzędzie Regulacji Energetyki, "Biuletyn URE” 2011, No. 1, pp. 40-45.

Consolidated text, Dz.U. (Journal of Laws) 2020, item 833. 
making an attempt by the recipient of gaseous fuel, electricity or heat, or prosumer who is a consumer - to contact the power company for the purpose of settling the dispute in directly ${ }^{37}$. The legislature has provided for similar conditions for an application to institute proceedings by the Coordinator for negotiations, like those in the instance of the Financial Ombudsman - as set out generally under Article 233(2) ADRkonsU, that is, the indication of the parties, precise specification of the request, indication of the type of proceedings in accordance with the applicant's choice under Article 3 ADRkonsU, and his/her signature.

Likewise, detailed rules of proceedings before the Coordinator for negotiations are set out in implementing regulations adopted under the Energy Law: Regulation of the Minister of Energy of 1 August 2017 concerning the conduct of out-of-court dispute resolution proceedings before the Coordinator for negotiations $s^{38}$ and Regulation of the Minister of Energy of 1 August 2017 concerning the financial thresholds of the value of the subject of litigation - if exceeded, the review of the dispute may be refused ${ }^{39}$.

In accordance with the formerly cited Regulation, the application for instituting proceedings shall be lodged in paper form at the address of the Energy Regulatory Office or in electronic form, including via the electronic platform of public administration services (ePUAP) or via the contact form provided on the Coordinator's website. By the same token, the indication of the form of electronic communication is much clearer to the addressee of the legal measure. Subsequently, under Article 2(1), upon receipt of the application for instituting proceedings, the Coordinator for negotiations institutes proceedings and notifies the parties about the institution of proceedings. Such notice is addressed to:

- the applicant:

- by registered mail, where the application is lodged in paper form, or

- by means of electronic communications, where the application is lodged in electronic form, including via the electronic platform of public administration services (ePUAP) or via a contact form provided on the Coordinator's website; - the power company by means of electronic communications or mail.

Under Article 4(1) of the Regulation of the Minister of Energy of 1 August 2017 concerning the conduct of out-of-court dispute resolution proceedings before the Coordinator for negotiations, the Coordinator informs the power company about the institution of proceedings, including its subject and specification of the

37 See: Article 31(d)(1) and (2) of the Energy Act.

38 Dz.U. (Journal of Laws) of 2017, item 1493.

39 Dz.U. (Journal of Laws) of 2017, item 1494. 
applicant's request, and about the legislation applicable in the matter, and prescribes a deadline of no less than 14 days for presenting its position with regard to the application. What is important, in contrast to the Financial Ombudsman, where the power company refuses to participate in the proceedings, or even fails to present a position, the Coordinator for negotiations shall terminate the proceedings and shall, without delay, advise the parties to this effect.

During the course of proceedings before the Coordinator for negotiations, further to Article 9(1) of the Regulation of the Minister of Energy of 1 August 2017 concerning the conduct of out-of-court dispute resolution proceedings before the Coordinator for negotiations, information is exchanged by means of electronic communication, in particular via e-mail, through the Coordinator's intermediation. However, where a party refuses to exchange information by means of electronic communication, then the exchange of information between the parties to the proceedings shall be effected by traditional mail. In such a situation, the length of the proceedings before the Coordinator for negotiations should not exceed 90 days.

Table 1. Comparison of selected features of the legal status and proceedings before the Financial Ombudsman and before the Coordinator for negotiations (prepared by the author).

\begin{tabular}{|c|c|c|}
\hline Criterion & Financial Ombudsman & Coordinator for negotiations \\
\hline Term of Office & 4 years & 4 years \\
\hline Appointing body & $\begin{array}{l}\text { President of the Council of } \\
\text { Ministers (Prime Minister) } \\
\text { at the recommendation of } \\
\text { the minister competent } \\
\text { in matters of financial } \\
\text { institutions }\end{array}$ & $\begin{array}{l}\text { President of the Energy Regulatory } \\
\text { Office }\end{array}$ \\
\hline $\begin{array}{l}\text { Requirements for candidates } \\
\text { (professional experience) }\end{array}$ & $\begin{array}{l}\text { Outstanding in knowledge } \\
\text { of the operation of financial } \\
\text { markets and of the legal } \\
\text { regulations governing its } \\
\text { environment, and at least } \\
\text { seven years of working } \\
\text { experience in this area }\end{array}$ & $\begin{array}{l}\text { At least a 5-year working experience, } \\
\text { including at least } 3 \text { years as an executive; } \\
\text { education in and knowledge of matters } \\
\text { in the sphere of the Coordinator's } \\
\text { responsibility }\end{array}$ \\
\hline $\begin{array}{l}\text { Requirements for candidates } \\
\text { (experience as an executive) }\end{array}$ & NO & YES \\
\hline $\begin{array}{l}\text { Decision-making powers or } \\
\text { power to impose }\end{array}$ & YES & $\mathrm{NO}$ \\
\hline Authorized ADR body & YES & YES \\
\hline
\end{tabular}




\begin{tabular}{|c|c|c|}
\hline Criterion & Financial Ombudsman & Coordinator for negotiations \\
\hline Options of ADR proceedings & $\begin{array}{l}\text { enables the approximation } \\
\text { of the parties' position } \\
\text { with a view to resolving } \\
\text { the dispute by the parties } \\
\text { thereto, or } \\
\text { presents a proposal for } \\
\text { resolving the dispute to the } \\
\text { parties thereto. }\end{array}$ & $\begin{array}{l}\text { enables the approximation of the parties' } \\
\text { position with a view to resolving the } \\
\text { dispute by the parties thereto, or } \\
\text { presents a proposal for resolving the } \\
\text { dispute to the parties thereto. }\end{array}$ \\
\hline $\begin{array}{l}\text { Conduct of ADR } \\
\text { proceedings }\end{array}$ & $\begin{array}{l}\text { Authorized person - } \\
\text { employee }\end{array}$ & In person \\
\hline Organizational autonomy & YES & $\begin{array}{l}\mathrm{NO} \text { - operates under the President of the } \\
\text { Energy Regulatory Office }\end{array}$ \\
\hline Support staff & Office & $\begin{array}{l}\text { Assistance provided by the Energy } \\
\text { Regulatory Office in the form of the } \\
\text { Coordinator's Team }\end{array}$ \\
\hline $\begin{array}{l}\text { Possibility of bringing } \\
\text { proceedings }\end{array}$ & YES & NO \\
\hline Proceedings commence: & $\begin{array}{l}\text { following an application } \\
\text { lodged by the customer of } \\
\text { the financial market player }\end{array}$ & $\begin{array}{l}\text { following an application lodged by } \\
\text { recipients of gaseous fuel, electricity or } \\
\text { heating for the household or prosumers } \\
\text { who are consumers }\end{array}$ \\
\hline $\begin{array}{l}\text { Responsibility of } \\
\text { participation of the } \\
\text { consumer's counterparty in } \\
\text { the ADR proceedings }\end{array}$ & $\begin{array}{l}\text { Participation of the } \\
\text { financial market player is } \\
\text { mandatory }\end{array}$ & $\begin{array}{l}\text { 1. The Coordinator informs the power } \\
\text { company about the institution of } \\
\text { proceedings, including its subject and } \\
\text { specification of the applicant's request, } \\
\text { and about the legislation applicable in } \\
\text { the matter, and prescribes a deadline of } \\
\text { no less than } 14 \text { days for presenting its } \\
\text { position with regard to the application. } \\
\text { 2. Where the power company, within the } \\
\text { prescribed deadline: } \\
\text { 1) fails to present a position with regard } \\
\text { to the application, or } \\
\text { 2) states that it refuses to participate } \\
\text { in the proceedings - the Coordinator } \\
\text { for negotiations shall terminate the } \\
\text { proceedings and shall, without delay, } \\
\text { advise the parties to this effect }\end{array}$ \\
\hline
\end{tabular}

\section{Conclusions}

The entry into force of ADRKonsU on 10 January 2017 marks the completion of the process of digitalization of dispute resolution with the participation of consumers via electronic forms, commenced by the adoption of the ODR Regulation in 2013. This is a great step forward in the creation of a common and single market. However, it has been demonstrated that the various institutions may differ in their legal status or in options of finalizing a particular dispute (for example, by an arbitration 
decision, which is not within the province of the Financial Ombudsman or Coordinator for negotiations). By the same token, in choosing an ODR body one must bear in mind that not all of them have the power to resolve the parties' dispute by delivering a decision.

However, it must be noted that digitalization cuts down expenses, the duration of disputes and provides a realistic option of achieving its final result. It must also be highlighted that this is of particular significance in the resolution of crossborder disputes within 90 days - where we encounter obstacles in the form of different national legal orders or language barriers. Furthermore, the use of the ODR platform is the possibility of going through intuitive steps with the assistance of complaint creators, recording drafts, and checking consumer rights, which is very convenient for consumers, who are not particularly proficient in the operation of mobile devices. Unfortunately, institutions of consensual dispute resolution are not too popular in Poland, and consequently, its impact is still rather small ${ }^{40}$. However, upon analysis of the specific number of cases, the institution of the Financial Ombudsman must be deemed as more effective, and in the author's view, the institution of the Coordinator for negotiations in the power sector should be adjusted in the direction of the Financial Ombudsman. As demonstrated by numbers, 620 cases were lodged with the Coordinator for negotiations in 2018, of which only $469^{41}$ satisfied the criteria which allow the qualification of the consumer's letter as an application and initiation of proceedings pursuant to it. At the same time, the number of applications lodged with the Financial Ombudsman and received by the Out-of-Court Resolution Dispute Section increased. This was an overall increase of 7\% (from 3,741 in 2017 to 4,014 in 2018). The total growing tendency in the number of cases lodged with out-of-court dispute resolution bodies justifies the forecast that along with growing consumer awareness, both ODR platform bodies will be approached more frequently.

40 Report for 2018, Coordinator for negotiations, https://koordynator.ure.gov.pl/kde/coordinator/ reports/266,Report-for-2018.html (accessed 31.07.2020).

41 In 2017, 382 cases were lodged with the Coordinator for negotiations, of which 156 satisfied the criteria which allow the qualification of the consumer's letter as an application and initiation of proceedings pursuant to it. Ibidem. 


\section{References}

Bełkowski J., O zadaniach Rzecznika Odbiorców Paliw i Energii, Biuletyn URE 2002, No. 5.

Bieliński A., Uwagi wstępne na temat mediacji, in: J. Olszewski (ed.), Sady polubowne i mediacja, Warszawa 2008.

Faliszek T., ODR. Rozpatrywanie sporów z zakresu sporów domenowych, in: B. Fuchs and J. Olszewski (eds.), Arbitraż. Między teorią a praktyką, Rzeszów 2014.

Figaszewska I., Zadania Rzecznika Odbiorców Paliw i Energii w Urzędzie Regulacji Energetyki, "Biuletyn URE” 2011, No. 1.

Gajda-Roszczynialska K., Mediacja obligatoryjna, "Polski Proces Cywilny” 2012, No. 13.

Kalak J., Pozasądowe postępowanie $w$ sprawie rozwiązywania sporów między klientem a podmiotem rynku finansowego, "Kwartalnik ADR" 2016, No. 2.

Koc K., Rzecznik Ubezpieczonych, in: A. Gronkiewicz (ed.), Instytucje ombudsmańskie w Polsce (wybrane zagadnienia), Częstochowa 2013.

Mania K., ODR (Online Dispute Resolution) - podstawowe zagadnienia, "Arbitraż i Mediacja” 2010, No. 2.

Mania K., Online Dispute Resolution, in: J. Czapska et al. (eds.), Mediacja. Teoria, normy, praktyka, Warszawa 2017.

Mroczyński-Szmaj Ł., Rola oraz ewolucja prawna instytucji Rzecznika Odbiorców Paliw i Energii w zakresie ochrony konsumenta, in: M. Czarnecka (ed.), Konsument na rynku energii elektrycznej, Warszawa 2013.

Okońska A., Mediacja - Austria, Niemcy, Szwajcaria, in: A. Torbus (ed.), Mediacja w sprawach gospodarczych. Praktyka - teoria - perspektywy, Warszawa 2015.

Pieckowski S., in: A. Szumański (ed.), Arbitraż Handlowy. System Prawa Handlowego, Vol. 8, Warszawa 2015.

Wahab M.S., Abdel, E. Katsch and D. Rainey, Online Dispute Resolution: Theory and Practice: A Treatise on Technology and Dispute Resolution, The Hague 2012.

\section{CITATION}

Mroczyński-Szmaj Ł., Digitalisation of ADR proceedings in consumer cases, with particular emphasis on the institutions of the Financial Ombudsman and Coordinator for negotiations, "Acta Iuris Stetinensis" 2021, No. 1 (Vol. 33), 115-132, 10.18276/ais.2021.33-07. 